\title{
Equal Protection of the Law: The Persons with Disabilities (Equal Opportunities) Act, 2014, Bahamas
}

\author{
Bernadette Bain \\ The College of The Bahamas ${ }^{1}$
}

\section{ABSTRACT}

The Persons with Disabilities (Equal Opportunities) Act, 2014 is a new and informative piece of legislation, the purpose of which is to provide equal opportunities for persons with disabilities. This paper explores the basis of the Act, which has its foundation in the United Nations Convention on the Rights of Persons with Disabilities. The legislation further facilitates the rights and freedoms provided under the Bahamian Constitution, and underscores fundamental rights. This analysis of the Persons with Disabilities (Equal Opportunities) Act, 2014, examines the nature and scope of equal rights and whether the Act provides adequate enforcement. The aim of the provisions is to restrict discrimination against persons with disabilities by providing opportunities on an equal basis and to require persons having dealings with the disabled to accommodate their needs. It is questionable whether the Act fulfils its purpose and whether penalties for failure to comply with the Act are adequate, as there is a lacuna or gap in the law, which hinders purposeful rights.

\section{INTRODUCTION}

There is no doubt that in recent years there have been increased efforts to educate communities on the rights of persons with disabilities. Various non-governmental organizations in The Bahamas have lobbied the Government on the rights of persons with disabilities, one being the Bahamas National Council for Disability (BNCD, formerly known as the Bahamas Council for the Handicapped) which was established in 1971 (Turnquest, 2014). The Council comprises general members and lobbyists, and includes committees which address vocational, educational, public relations, medical and other issues (www.bncdbahamas.org). The
BNCD is a forum for the exchange of ideas, it advocates for the rights of persons with disabilities, and facilitates follow-up with the government and private sector. It was through the constant surveillance and agitation of the BNCD that conclaves and conferences were organized to address the needs of persons with disabilities in The Bahamas. In 1994, the BNCD held a conference which resulted in the Declaration on the Rights of Disabled Persons in The Bahamas (Bahamas Ministry of Housing and Social Development, 1999). This was followed in $1995-96$ by active participation in the production and amendment of the Government's green paper discussion document, National Policy

\footnotetext{
${ }^{1}$ Bernadette Bain, School of Social Sciences, Law School, The College of The Bahamas, P.O. Box N-4912, Nassau, Bahamas.

E-mail: bernadette.bain@cob.edu.bs

APA reference: Bain, B. (2016). Equal protection of the law: The Persons with Disabilities (Equal Opportunities) Act, 2014. The International Journal of Bahamian Studies, 22, 7-15. http://dx.doi.org/10.15362/ijbs.v22i0.267
}

(C) B. Bain, 2016. Journal compilation @ The International Journal of Bahamian Studies, 2016 
Statement for Persons with Disabilities (1996). Following a disability conclave and the formation of the National Task Force on Disability in 1998, the BNCD was instrumental in the production of a white paper, Report of the National Task Force on Disability (1999). Before tabling the report in the Bahamas House of Assembly on February 9, 2000, Minister of Social Development Algernon Allen led persons with disabilities, members of associations, professional groups and other stakeholders on a historic march to Rawson Square. Following town meetings hosted by the BNCD in New Providence, Grand Bahama, Exuma and Abaco, in March 2014 Minister of Social Services and Community Development Melanie Griffin announced that the legislation was in its final stages (Ingraham, 2014).

Public pressure resulted in the enactment of the Persons with Disabilities (Equal Opportunities) Act, 2014. At the outset of the Act (2014), one is cognizant that the guiding principles of this enactment are provided in the United Nations Convention on the Rights of Persons with Disabilities, 2006 (the Convention). The primary principle in the Convention's preamble provides that "States Parties to the Convention should not have different treatment of persons as a result of their disability". The principles in the Charter of the United Nations recognize the inherent dignity and equal rights of all members of the human family as the foundation of freedom, justice and peace (United Nations Convention on the Rights of Persons with Disabilities, 2006). In addition, the Constitution of The Bahamas (1973) affirms equal protection of the law through its provisions of fundamental rights, freedoms and protection from discrimination. The main aim of this paper is to examine the provisions of the Act (2014), by analyzing whether the enactment exhibits the principles of human rights with particular reference to fundamental freedoms in society.

\section{THE LEGAL FRAMEWORK}

The Constitution of The Bahamas (1973), by virtue of Article 2, is the supreme law of the Commonwealth of The Bahamas, and if any other law is inconsistent with the Constitution, the Constitution shall prevail and the other law be void for inconsistency. In other words, all other laws must be intra vires the Constitution. Therefore, Parliament itself must conform to the principles and tenets of the supreme law, which guides its enactments; it cannot legislate outside the powers of the Constitution. The Constitution affirms the fundamental rights and freedoms of all persons (The Constitution of The Bahamas, 1973, Art. 15). It is against this background that the Act was legislated. Section 2 defines "persons with disabilities" as:

... persons with a long term disability including physical, mental, intellectual, developmental or sensory impairments and other health related illnesses, which in interaction with various barriers may hinder full and effective participation in society on an equal basis with others.

Part I of the Act (2014) contains interpretation and guiding principles. In Part II, section 4, the Act provides for the establishment of a National Commission for Persons with Disabilities. The Commission is a body corporate, and is capable of suing and being sued. Section 10 of the Act (2014) outlines the functions of the Commission. Section 10 (1)(b)(iii) mandates the Commission to "recommend measures to prevent discrimination against persons with disabilities." It further makes provision to have persons with disabilities registered with various institutions, associations, organizations, including those controlled and managed by the Government and local authorities (Persons with Disabilities [Equal Opportunities] Act, 2014, p. 7). 
Part III of the Act (2014) deals with the rights of persons with disabilities. Most significant is that persons with disabilities should be given equal access to opportunities for suitable employment. Section 14(1)(2) mandates that a qualified employee with a disability be given the same compensation, privileges, and benefits as able-bodied employees (p. 10). The Act (2014) prohibits employers from discriminating against persons with disabilities in the determination of wages, pensions or other benefits, inclusive of training or promotion. In particular, employers should not discriminate in relation to advertisement and recruitment for employment, and every employer with more than 100 employees should employ not less than $1 \%$ of persons with disabilities. On the other hand, an employer shall not be considered to have discriminated against a person with a disability if the act or omission alleged to constitute the discrimination was not primarily attributable to the disability of the person. Where a person with a disability feels discriminated against by an employer, that person may complain to the Commission, which may take action as it sees fit (Persons with Disabilities (Equal Opportunities) Act, 2014, s. 16, p. 10).

The right to health care service is an important aspect of the Act (2014), where section 18(1) provides that a person with a disability shall be afforded "the same quality and standard of affordable healthcare treatments" (p. 12). In furtherance of adequate health care, it is the responsibility of the Minister of Health and relevant health and rehabilitative authorities to ensure that medical and para-medical personnel are adequately trained to provide care for persons with disabilities. It is the responsibility of the Minister of Health to ensure that all community and health clinics are made accessible to persons with disabilities.

Section 20 provides that "every person with a disability shall be entitled to a barrier-free and disabled friendly environment to enable him to have to access buildings, Information Communication Technology (ICT), roads and other social amenities, and assistive or adaptive devices and other equipment to promote his mobility" (p. 12) and "A proprietor of any building to which the public is permitted access shall adapt it to suit persons with disabilities in such a manner as may be specified by the Commission" (s. 21, p. 12). Further, paragraph 3 of Section 21 states that "All proprietors of buildings shall designate parking for persons with disabilities within six months of the coming into operation of this Act" (p. 13). Section 22 indicates that it is the responsibility of the Commission to collaborate with the Minister of Transport to formulate a policy for public transportation (p. 13).

Part IV of the Act (2014) provides for Adjustment Orders for premises usually open and providing services to the public are accessible to persons with disabilities (p. 15). In the event that there is a structural, administrative or other impediment to access such premises, the Commission may serve the owner of the premises an adjustment order, which may in part, require the owner to undertake at his own expense changes to make their premises accessible by persons with disabilities. It is important that every person with a disability has access to a barrier-free, disabled-friendly environment. A person with disability cannot be denied access to any premises or services by reason of their disability alone (p. 16). A person found guilty of the offence is subject to a fine of $\$ 5,000$ or three months in prison, or both (s. 29(2), p. 17). In addition to this penalty, a denial of entrance may be considered an injury of which the injured party may recover summarily as a civil debt (s. 28, p. 16).

In Part V, Education, section 31 (1), provides that the Minister responsible for education, 
after consultation with the Commission, shall formulate a National Education programme to ensure that learning institutions take into account special needs of persons with disabilities with respect to entry requirements, services and other relevant matters (p. 17). There should be an integrated system of special education, including Braille, along with special education programmes in the Family Islands (s. 33(3), p. 18).

Part VI, section 35 provides that a National Development Fund for Persons with Disabilities is established to benefit people with disabilities. Part VII provides for custom exemptions of all goods or equipment donated to institutions or for persons with disabilities under certain conditions (s. $38 \& 39$, p. 20).

Part VIII, sections 41-55, lays out miscellaneous provisions, including those involving the legal system, where the Rules Committee of the Supreme Court is able to exempt persons with disabilities from paying of fees in relation to any court proceedings commenced under the Act. Under section 48, any parent, guardian or next of kin who conceals any person with a disability is guilty of an offence and summary conviction or fine or both (p. 23). Further, section 51 provides for a general penalty if a person is found guilty of an offence, where there is not a specific penalty (p. 23). The Commission may request the Attorney General to take appropriate legal action if it is believed that a person or group of persons is engaged in discriminatory practice. In the event that any person or group of persons feels aggrieved by an order in a legal action, he/she may apply to the Supreme Court within 60 days for a review of the order.

It should be noted that where a person is in violation of the Act (2014), he or she bears the burden of presenting an evidential case after which the burden shifts to the alleged discriminator to disprove the allegations.

\section{CONSTITUTIONALITY OF RIGHTS}

The intent of the Act is to provide equality by preventing discrimination of persons with disabilities. The measures adopted are taken to correct or enable persons with disabilities to carry on normal day-to-day activities like able-bodied persons. The practical result of such measures would equalize opportunities for persons with disabilities.

Constitutionality of rights remains fundamental to the Constitution of The Bahamas (1973), where Chapter III article 15 states:

Whereas every person in The Bahamas is entitled to the fundamental rights and freedoms of the individual, that is to say, has the right, whatever his race, place of origin, political opinions, colour, creed or sex, but subject to respect for the rights and freedoms of others and for the public interest, to each and all of the following, namely-life, liberty, security of the person and the protection of the law.

The foregoing article of the Constitution is consistent with those of other Commonwealth Caribbean countries with written constitutions (Plimmer, 1998). In the case of Minister of Home Affairs v. Fisher (1980), the Judicial Committee of the Privy Council, which is the final Court of Appeal of The Bahamas, pointed out that Caribbean constitutions are headed by a chapter: Protection of Fundamental Rights and Freedoms of the Individual. Further, that the constitutions of most Caribbean territories were greatly influenced by the European Convention for the Protection of Human Rights and Fundamental Freedoms (1953), which had been influenced by the United Nations Universal Declaration of Human Rights (1948). The effect is to afford protection to any individual's rights and freedoms, without prejudice.

In Thornhill v. Attorney General of Trinidad 
and Tobago (1980), their Lordships affirmed that under the Constitution of Trinidad and Tobago and the commencement of the Constitution of 1962, the existing rights and freedoms "shall continue to exist" (p. 32). That in the context of the Commonwealth Caribbean constitutions, fundamental rights and freedoms are not terms of "legal art", but are statements of principles of great breadth and generality, expressed in the kind of language more commonly associated with political manifestos or international conventions, like the United Nations Universal Declaration of Human Rights of 1948, and the European Convention for the Protection of Human Rights and Fundamental Freedoms (1953). In other words, the essence of fundamental rights and freedoms presupposes that each person, regardless of class, status or ability shall be afforded equal rights and protection from discrimination (The Constitution of The Bahamas, 1973, art. 26).

In adhering to the principles of The Constitution of The Bahamas (1973), the Act (2014) aims not only to fulfil the constitutionality of rights in The Bahamas, but to adhere to international standards of human rights. Clark (2012) avers that equality before the law is a fundamental human right as enshrined in various United Nations documents (p. 221).

The Bahamas became a signatory to the United Nations Convention on the Rights of Persons with Disabilities (2006), Treaty Obligations on September 24, 2013. The Convention (2006) in its preamble and protocol, declares that, States which are Parties to the Convention, recognise the inalienable rights of all members of the human family:

the United Nations, in the Universal Declaration of Human Rights and in the International Covenants on Human
Rights, has proclaimed and agreed that everyone is entitled to all the rights and freedoms set forth therein, without distinction of any kind.

In affirming the rights of every person, the Convention (2006), seeks to ensure the rights of, and prevent discrimination against persons with disabilities in all countries. Vanhala (2010) points out that in Canada the adoption of the United Nations Convention on the Rights of Persons with Disabilities in 2006 was a milestone in a process of attaining rights for disabled people, which translated citizenship demands into the language of rights, by providing a disability rights discourse on the international level.

This is seen in rights under Commonwealth Caribbean constitutions, the effect of which was seen in the Bahamian case of Commissioner of Police v. Davis (1993). The Justices considered article 20(1) of the Constitution of The Bahamas which provides that any person charged with a criminal offence should be afforded a fair hearing within a reasonable time by an independent and impartial court established by law. The relevant provision is found in Chapter III, under the Protection of Fundamental Rights and Freedoms of the Individual, whereby article 20(1) provides that "If any person is charged with a criminal offence, then, unless the charge is withdrawn, the case shall be afforded a fair hearing within a reasonable time by an independent and impartial court established by law."

In the Commissioner of Police v. Davis (1993), the Court determined that the transfer of the jurisdiction from the Supreme Court to the Magistrate's Court would be unconstitutional. Under the Bahamian Constitution, it is a characteristic of offences charged on information in the Supreme Court that the defendant is entitled to trial by jury. The Privy Council noted that the Legislature, 
by vesting in the Magistrate's Courts a jurisdiction to try offences, which under the Constitution are triable only in the Supreme Court, would deprive the defendant of his constitutional right to a jury trial, as the Magistrate's Court had no such jurisdiction. This judgment is the essence of constitutionality of rights and equal protection under the law.

This core principle of constitutionally of rights being inclusive and applicable to persons with disabilities was affirmed by the Privy Council in the case of Matadeen v. M. G. C. Pointu (Mauritius) (1998). Their Lordships noted that "a Constitution concerned to protect the fundamental rights and freedoms of the individual should not be narrowly construed in a manner which produces anomalies and inexplicable inconsistencies" (para. 27). Their Lordships noted that the concept of discrimination in section 16 of the Mauritian Constitution involved not only the difference of treatment but the absence of valid reason for the difference.

The Privy Council again in the Mauritian case of Bishop of Roman Catholic Diocese of Port Louis v. Tengur (Mauritius) (2004), dealt with discrimination under the Constitution. In this case a group of some 12 secondary schools in Mauritius, which together have been called the Catholic colleges, was administered by the Roman Catholic Board. The Catholic Board, with the Government of Mauritius, made $50 \%$ of places available to the Government, allocating them to pupils according to merit. The applicant was the father of an 11-year old Hindu girl who was approaching the end of her primary education and awaiting allocation to a secondary school. The Appellants were the Catholic Board. Her father feared that the allocation system might prejudice his daughter's admission to one of the Catholic colleges if she did not score highly enough in the examination to win a place within the
Government's 50\% allocation, but did score highly enough to win a place within the Catholic colleges' $50 \%$, if those places were to be allotted on the basis of examination results alone and without regard to religious affiliation. He challenged the constitutionality of these arrangements made and operated by the Minister of Education. The Privy Council determined that the father's claim was valid and that the giving of preference to one group of applicants necessarily works to the disadvantage of any group of applicants to whom preference is not given.

Their Lordships observed, in relation to the reserved places, that although the appellants' intention was to maintain the religious and moral character and ethos of the Catholic colleges by recruiting enough Roman Catholic pupils to balance the school's population a gesture that was understandable and admirable, the intention of the Board involved differentiating between one pupil and another. The Privy Council, however, made clear that differentiation without more evidence was not enough to enable the father to succeed. Referring to Rault J in Police v. Rose (1976), the Privy Council noted that:

To differentiate is not necessarily to discriminate. As Lysias pointed out more than 2,000 years ago, true justice does not give the same to all but to each his due: it consists not only in treating like things as like, but unlike things as unlike. Equality before the law requires that persons should be uniformly treated, unless there is some valid reason to treat them differently (p. 81).

The Privy Council ruled that if there is difference of treatment it will be justified when it pursues a legitimate aim and there exists at the same time a reasonable relationship of proportionality. The alleged discriminator must justify it as having a legitimate aim and as having a reasonable 
relationship of proportionality between the means employed and the aim sought to be realised. The Privy Council stated that the Constitution was clear and unambiguous and must be given effect as the Supreme Law of Mauritius. It reaffirmed the constitutionality of rights, referring to its decision in Société United Docks v. Government of Mauritius (1985), where it said that: "A Constitution concerned to protect the fundamental rights and freedoms of the individual should not be narrowly construed in a manner which produces anomalies and inexplicable inconsistencies" (p. 599). This would be in keeping with the earlier judgment by the Privy Council in the Bahamian case of Commissioner of Police v. Davis (1993), where their Lordships affirmed that sections 22(8) to (11) of the Dangerous Drugs Act infringed the Constitution of The Bahamas and further deprived the accused of their constitutional right to trial by jury. In other words, there must be a balancing of rights as between the person alleging discrimination and the discriminator.

\section{THE FORCE OF LAW}

In acknowledging the constitutionality of rights, it is important that a person show that he is one who has been "wrongly deprived of" or refused something to which he is legally entitled. In categorizing the rights of persons with disabilities, emphasis is placed on accessibility and mobility, where the person "shall be entitled to a barrier free and disabled friendly environment" (2014, s. 20, p. 12). It is mandatory that buildings and roads have assistive or adaptive devices to promote mobility. Whenever an Act declares a thing mandatory, then the courts must follow its declaration and enforce the law.

Where the Commission considers that premises are inaccessible, the Commission may issue an adjustment order, requiring the owner or provider to comply with the Act. Although there is no provision in the Act, whereby the Commission can enforce the adjustment order, a person against whom an order is made may appeal to the courts, under section 27(4) that: (a) he cannot afford to bear the costs; (b) the period for implementation is unreasonable; (c) the nature of the action is unreasonable; or (d) the premises concerned may be secured without requirements stipulated in the adjustment order. It should be noted that although the Commission is given discretion when making a determination as regards an adjustment order, it is not a court of law and does not have the power to enforce any part of the Act. It is clear that persons with disabilities will find this provision challenging when trying to have their rights enforced and will find it necessary to seek judicial redress.

As to the court's duty to enforce the law, the courts are bound by what is reasonable in balancing rights, to ensure justice is served. In this regard, the courts have developed the test of Wednesbury reasonableness, and what is proportional. In the case of Council of Civil Service Unions v. Minister for the Civil Service (1985), Lord Diplock examined whether a decision made by a public body was so irrational that it defied logic. In addition, the Privy Council in De Freitas v. Permanent Secretary of Ministry of Agriculture, Fisheries, Lands and Housing (1999), drawing on South African, Canadian and Zimbabwean authorities, defined the questions generally to be asked in deciding whether a measure is proportionate:

whether: (i) the legislative objective is sufficiently important to justify limiting a fundamental right; (ii) the measures designed to meet the legislative objective are rationally connected to it; and (iii) the means used to impair the right or freedom are no more than is necessary to accomplish the objective (p. 80).

Their Lordships determined that the 
formulation of proportionality often cited as regards to decisions made by public bodies, was deficient in omitting the requirement for the need to "balance the interests of society with those of individuals and groups" which was featured in the judgment of Dickson CJ in R. v. Oakes (1986, p. 227). Noting that in determining the questions of proportionality, the court must strike "a fair balance between the rights of the individual and the interests of the community" (R. (Razgar) v. Secretary of State for the Home Dept., 2004, para 20). Decisions must be reasonably justified, with the quality of reasonableness even when attempting to enforce rights. The means used must not be more than necessary to satisfy the legislative intent. While enforcing the Act, to ensure justice, and at the same time prevent discrimination against persons with disabilities, there must be a balancing approach. The courts must balance this right with reasonableness as it relates to the Commission's adjustment order and the discriminator.

\section{CONCLUSION}

A step in the right direction is one way to describe the Persons with Disabilities (Equal Opportunities) Act, 2014. The Bahamas as a signatory to the Convention (2006) undertook its treaty obligations to secure rights and freedoms for persons with disabilities by enacting this piece of legislation. The Act of 2014 contains provisions designed to help reduce discrimination and to require persons having dealings with them to accommodate their needs and one is aware of the principles of human rights. The fact that persons with disabilities may find the process challenging should not be a deterrent to address issues of discrimination. The concept and the aim remain of practical importance on issues of rights and discrimination. Although it provides only limited enforcement and penalties, the legislation is in keeping with the basic principles of human rights and must be seen as an important building block to achieving full rights for the disabled.

\section{REFERENCES}

Bahamas National Council for Disability [web page]. (2015). Retrieved from http://www.bncdbahamas.org

Bahamas. Ministry of Housing \& Social Development. (1996). National policy statement for persons with disabilities. Nassau: Author.

Bahamas. Ministry of Housing \& Social Development. (1999). Report of the National Task Force on Disability. Nassau, Bahamas: Author.

Clark, M. (2012). The human right of the disabled to access justice: An imperative for policing. The Police Journal, 85(3), 221-234. http://dx.doi.org/10.1350/ pojo.2012.85.3.584

Ingraham, F. (2014, March 27). "Bahamas disability bill one step closer to reality." Retrieved from http://www.thebahamasweekly.com/publis h/local/Bahamas_Disability_Bill_one_step _closer_to_reality33958.shtml

Plimmer, M. (1998). Standing in someone else's shoes: The incorporatio of the ECHR and the provision in the Human Rights Bill argues that there are lessons to be learnt from Commonwealth Caribbean constitutional law. The New Law Journal, 148(6848), 1026-1027.

Turnquest, A. (2014, June 5). Disability legislation defended. The Tribune. Retrieved from http://www.tribune242.com/news/2014/jun /05/disability-legislation-defended/

Vanhala, L. (2010). Twenty-five years of 
disability equality? Interpreting disability rights in the Supreme Court of Canada. Common Law World Review, 39(1), 27-47. http://dx/doi.org/10.1350/clwr.2010.39.1.0 194

\section{Cases, Conventions and Law Reports}

Bahamas Independence Order 1973, no. 1080:

The Constitution. (1973). Nassau, Bahamas: Government of The Bahamas. Retrieved from http://laws.bahamas. gov.bs/cms/images/LEGISLATION/SUBO RDINATE/1973/1973-1080/TheBahamas IndependenceOrder1973_1.pdf

Bishop of Roman Catholic Diocese of Port Louis v. Tengur, (Mauritius) (2004). UKPC 9. Retrieved from http://www.saflii.org/mu/cases/ UKPC/2004/9.pdf

Commissioner of Police v. Davis (1993) 3 WLR 846.

Council of Civil Service Unions v. Minister for the Civil Service (1985) 1 AC 374.

De Freitas v. Permanent Secretary of Ministry of Agriculture, Fisheries, Lands and Housing (1999) 1 AC 69.

European Convention for the Protection of Human Rights and Fundamental Freedoms. (1953). Retrieved from http://www.echr.coe.int/ Documents/Convention_ENG.pdf
Matadeen v. M. G. C. Pointu (Mauritius) (1998) UKPC 9. Retrieved from http://www.bailii.org /uk/cases/UKPC/1998/9.html

Minister of Home Affairs v. Fisher (1980) AC 319.

Persons with Disabilities (Equal Opportunities) Act (2014) Bahamas (No. 31 of 2014). Retrieved from http://www.ilo.org/dyn/natlex/docs/ELECT RONIC/90308/120377/F1133270545/BHS90308.pdf]

Police v. Rose (1976) MR 79.

R. (Razgar) v. Secretary of State for the Home Dept. (2004) UKHL 27.

R. v. Oakes (1986) 1 SCR 103.

Société United Docks v. Government of Mauritius (1985) AC 585.

Thornhill v. Attorney General of Trinidad and Tobago (1980) 31 WIR 61 PC, 2 WLR 510.

United Nations. (1948). Universal declaration of human rights. Retrieved from http://daccessddsny.un.org/doc/RESOLUTION/GEN/N R0/043/8 8/IMG/NR004388.pdf?OpenElement

United Nations. General Assembly. (2006). Convention on the Rights of Persons with Disabilities. Retrieved from http://www.un.org/disabilities/ 